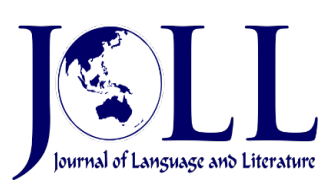

Vol. 21 No. 2, October 2021, pp. 294-306

DOI: 10.24071/joll.v21i2.3122

Available at https://e-journal.usd.ac.id/index.php/JOLL/index

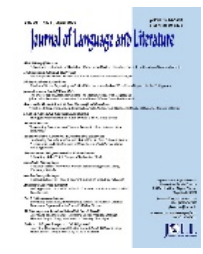

This work is licensed under a Creative Commons Attribution-ShareAlike 4.0 International License.

\title{
Women and Matrimony: A Study of Mona Lisa Smile
}

\author{
Pei-Yu Chao' ${ }^{1} \&$ Ya-huei Wang1, 2* \\ qq0970565666@gmail.com \& yhuei@csmu.edu.tw \\ ${ }^{1}$ Department of Applied Foreign Languages, Chung Shan Medical University, TAIWAN \\ $2^{*}$ Department of Medical Education, Chung Shan Medical University, TAIWAN
}

\begin{abstract}
This study intended to use the film Mona Lisa Smile (1993) as an example to examine how women in the traditional generation of 1950 were gender stereotyped and used to trade themselves off through marriage in consideration of a cost-and-benefit analysis. However, as the change of women's gender consciousness from the conservative to the feminist in the USA of 1950, women began to realize their potential and subjectivity, hence questing for liberal spirit and autonomy to choose their career and husbands based on love. The researchers used the qualitative method, with both the primary and secondary data, to facilitate a latent-content analysis. After conducting a content analysis of the film and the script of Mona Lisa Smile, the researchers took notes regarding gender stereotyping and conventional gender norms in social interactions and conducted a literature review of Becker's side bet theory and Homan's social exchange theory to investigate how women in America in the 1950s were disciplined to meet the expectation of social norms to fit the notion of conventional matrimony, and how people, both men and women, while choosing their mates, seek the maximum interest and minimum cost. The film Mona Lisa Smile lets readers have a chance to see the transformation of a marital relationship from the old days to modern ones. With raised gender consciousness, women may now subject their choices to their own will and, hence, apply a different definition to the word "marriage."
\end{abstract}

Article

Keywords: matrimony; gender stereotype; gender awareness; side bet theory; social exchange theory

\section{Introduction}

Women in the traditional generation of the 1950s, with the acquisition of manners and rules enacted by social norms, were gender stereotyped to be a functional character willing to sacrifice themselves to help men, to procreate, and to tend all of the chores. According to Becker's side bet theory, matrimony can be recognized as a fair trade of commitments: "Commitments come into being when a person, by making a side bet, links extraneous interests with a consistent line of activity" (Becker, 1960, p. 32). Based on 
Becker's side bet theory, people always make choices assuming the "risk" and the "remuneration" of an event or an investment in advance. This means that fairness can build harmony in matrimony, in that, if the risk and the remuneration can reach a balance, the commitment could continue for a long time.

Becker's side bet theory (1960) is associated with Homan's social exchange theory, which was proposed in 1961. Homan mentioned that social behaviors are the result of a two-sided exchange process involving giving something and getting something in return. Because the core of social exchange theory is to minimize the cost and to maximize the benefit, the decisions and actions people undertake would be based on the consequence of the cost and benefit. In other words, based on the social exchange theory, people would measure social interactions against the benefits that may be derived from them (Lawler, 2001). Homan (1961) also introduced a "rationality proposition," asserting that, when people are vacillating in making a decision between alternative actions, they choose the action whose resulted value, multiplied by the probability of gaining the result, is greater. Both Becker's side bet theory and Homan's social exchange theory emphasize the cost-benefit analysis, by which, while making a decision, people will follow the direction of maximum interest and minimum cost.

This study intended to use the film Mona Lisa Smile (1993) as an example to illustrate how women have been gender stereotyped and used to trade themselves off through marriages. Hence, in addition to use gender ideology to define ideal women for the expectations of public and social norms, the study also examined how women themselves in 1950's had been used to choose to marry rich men in the marriage institution in terms of Becker's side bet theory (1960) and Homan's social exchange theory (1961). However, as the awareness of women's gender consciousness in the USA of 1950, women sought more freedom to choose their career and husbands based on love (Friedan, 1997; Lam, 2011).

\section{Methodology}

In order to examine how women in the traditional generation of 1950 were gender stereotyped and used to trade themselves off in the marriage institution in consideration of the consequence of a cost-benefit analysis, taking the film Mona Lisa Smile (1993) as an example, the researchers conducted the research, using the qualitative method, with both primary and secondary data, to facilitate a latent-content analysis (Babbie, 1995). After conducting a content analysis of the film and the script of Mona Lisa Smile, the researchers took notes regarding gender stereotyping and conventional gender norms in social interactions and conducted a literature review of Becker's side bet theory (1960) and Homan's social exchange theory (1961) to investigate how women at Wellesley College in America of 1950 were disciplined to meet the expectation of social norms and to fit in with the ideals of conventional matrimony and how people, both men and women, while choosing their mates, follow the direction of maximum interest and minimum cost. In addition, with the initiation of feminist movement in the USA of 1950, a movement claiming that men and women should be treated equally in any field of life, women's gender consciousness has been changed from the conservative to the feminist and hence those women in Mona Lisa Smile begin to realize their potential and subjectivity. Therefore, they quest for liberal spirit and autonomy to choose their career and husbands based on love.

\section{Results and Discussion}

\section{Feminine Mystique in the Patriarchal Ideology}

Women have dreamed of having a good husband and a "perfect" family: a family with no fights, with children around, and no worries about money problems. This was no exception for women in the 1950s in America (Lamb, 2011). Hence, in order to let themselves be marriable, American women in the 1950s had to fit the image of the ideal woman, as what Friedan (1997) called the "feminine mystique," which was being promoted in radio programs and commercials at that time. To emulate the 
"feminine mystique," women made themselves "feminine" by being passive, obedient, and capable of managing the household. Their goal was to trade themselves off to get married.

Hence, in these programs and commercials, women were portrayed as being fond of cooking, clothing, and cosmetics, with no passion for the pursuit of knowledge or selfthought. They were depicted as having nothing to do except housework and keeping themselves beautiful in order to be married off. For these women, the only passion was their life's goal: to pursue a man and trade themselves off to him (Friedan, 1997). While accessing these programs, magazines, or commercials, women were being socialized into the preestablished patterns of gender behavior, assimilating themselves with the expectation of social norms and the marriage institution.

The film Mona Lisa Smile, set in the United States of 1953 and directed by Konner and Rosenthal in 1993, reveals the attitude of women in 1950s America toward marriage. In terms of the education configuration of polite company, like Wellesley College in Mona Lisa Smile, these finishing schools were dominated by traditionalists who guided girls to become the ideal feminine characters of that time. For instance, the president of Wellesley College, Miss Carr, urged girls to dedicate themselves to only propagating and taking care of their husbands for the rest of their lives. Thus, in addition to acquiring professional knowledge and etiquette, all the girls studying at this college cared about was finding a husband and then building their family. This situation may cause the feminist consciousness to be downcast and let women almost rely on men instead of being independent, with their own thoughts or vocations.

According to Becker's (1960) side bet theory, people generally choose a partner based on the assumption of a continued and stable matrimony and then increase their commitment to gain more interest. Hence, based on the previous experiences of their ancestors, women may choose a man who is more suitable for them or may choose a companion who has outstanding prospects when seeking marriage. It is said that women make a "side bet"' based on a main bet, or the activity succeeding it; the side bet thereby increases their commitment to the main bet. Conversely, if they fail at the main bet, they would also lose the side bet (Becker, 1960; Aranya \& Jacobson 1975). Hence, running a marriage is somewhat like running a business or organization. Indeed, Becker (1973) mentions in his theory of marriage that, in each marriage, the husband and the wife are like a two-person company, with one being the entrepreneur to organize the business and the other one being hired to run the business. In this two-person firm called matrimony, in order to minimize the cost and to maximize the benefit, it is necessary to arrange optimal mating in order to "hire" the mate who is capable of bringing maximal benefits to the family (Becker 1973).

Therefore, in order to let themselves be "hired," or married off, in the competitive marriage market, women have to equip themselves with feminine characteristics so that they become competitive, endeavoring to demonstrate that they can bring the maximal total utility, or happiness, to the marriage (Becker, 1991).

Based on these theories, in interpersonal relations, people also take advantage of the exchange theory. They tend to pay little in exchange for the best benefit. The cost is the part that people want to avoid. In matrimony, for example, in order to reach marital happiness, both men and women would definitely avoid partners with bad habits and negative personalities. Moreover, in order to avoid a high cost and to maximize the benefit of matrimony via the cost-benefit analysis, both men and women would keep away from someone in a low social status because marrying such a person would deduct from the highest benefit or even render the cost higher than the benefit.

Therefore, in order to maximize the benefit and minimize the cost, with respect to committing to matrimony, people would choose partners with a higher social status and economic situation or, at least, those with the same social status or economic situation. Thus, based on Becker's side bet theory (1960) and Homan's social exchange theory (1961), once 
one is considering matrimony, as in Mona Lisa Smile, both men and women would choose to enter polite company in order to maximize their benefit, symbolizing the exchange values in the marriage market. As shown in Mona Lisa Smile, Spencer, a wealthy man, chooses Betty, a rich girl with proper etiquette-not a mediocre girl next door-to be his wife in order to reap the maximal benefits for the household. Hence, some potential failures, like screwing up a banquet and losing face, will be avoided in his social interactions. Apart from men, women experience the same phenomenon. Both men and women prefer assortative mating in some way, which refers to the nonrandom mating in the marriage mating market based on the principle of social exchange theory (Buss, 1984). However, women's marriage decision would be more likely to be conditioned by the dominant patriarchal ideology (Castro, 1990; Millet, 1985).

Based on the assortative mating strategy, Becker's (1960) side bet theory, and Homan's (1961) social exchange theory, it seems reasonable that, in Mona Lisa Smile, Betty Warren, a college student in a finishing school, wants to marry a husband whose status and background are similar to hers. Betty is a classic character who always considers her marriage impartially and rationally. She inherits this traditional concept from her mother and always complies with her mother's words. In Becker's side bet theory (1960), marrying a competent man corresponds to having the security of indemnity in her marriage, in that the marriage guarantees financial security or protection. Hence, while rationally seeking a competent man, Betty would feel secure if she gained enough financial support. However, if she cannot get the right person, that is, the person meeting her expectations, she would lose her livelihood. Hence, Betty prepares for her marriage diligently, with numerous expectations. She invests her time, money, and capital to make herself a "qualified" wife in order to exchange financial security for her future life. According to her concept, spending these funds to trade herself off in marriage is relatively worthy. Ultimately, as in the costbenefit analysis, Betty and her husband Spencer are married. Under Becker's side bet theory (1960), their marriage is a product made by an equitable transaction. Spencer's role props the household expenses up; Betty's character completes the household tasks all the time. The husband, Spencer, is responsible for external matters, while the wife, Betty, dedicates herself to the internal household. While making a side bet, both Spencer and Betty (the husband and the wife) compensate each other and get a good deal on this marriage transaction.

Through a typical feudal outlook, the social status of a woman is increased by marrying a man; so are the sources of finance. Women must rely on men for their livelihoods. In a patriarchal society, the value of women comes from exchanging obligations and delivering babies. In other words, the benefit of matrimony to women depends on the comparison of income and domestic work and the comparison of the social/economic status between the men and women. In the past, men were good at earning remuneration from labor markets; they earned much more than women. On the other hand, women were good at household chores. They took care of all daily living tasks. They also successfully supported each other: men won support and care from women, while women obtained economic dependence and other material support from men.

However, there are some limitations to Becker's side bet theory (1960). Although women will gain equal benefits or interests from their husbands in their marital relationship in terms of social exchange conditions, there is a factor called "gender role" that diminishes their happiness in matrimony. Gender role is one of the factors that decides the social status of a person. In a traditional society, women are at a lower social status, having few or no chances to declare their right to pursue careers or an education. Thus, women became accustomed to heavily relying on their husbands, resulting in their lower level of feminist consciousness and subordinate status in matrimony.

\section{Women in Functional Marriages}

In a conservative society, such as the society of 1950s America, matrimony abides 
by conventional social norms, in which almost all women have an expectation of marriage; indeed, matrimony is an important milestone in their life. With this concept, if they do not marry, they cannot have their own family, and hence, they would become a loser. In Mona Lisa Smile, Katherine, an art professor, has a talk with President Carr at the presidential office. While observing that half of the girls at Wellesley College are about to get married to obtain financial support for the rest of their lives, in a conversation with her, Katherine realizes that President Carr is proud that these girls will get married after attending the finishing school.

Katherine: These girls... Are you proud, President Carr?

President: Yes, actually, I am.

Katherine: Well, you should be, I guess. Half of them are married. The other half, give it a month or so. It's really only a matter of time. They're biding time until somebody proposes!

President: A hundred years ago, it was inconceivable for a woman to be a college graduate. Perhaps you should look back to see how far we've come.

Katherine: I'm sorry, from where I sit, it's just a different kind of corset. Well, we can all use a little support. 101:04:4701:05:12)

Ironically, for these girls, the education they receive prepares them to be a good housewife and mother, not to search for subjectivity and independence. Upon the first day of school, Katherine even wonders if these female students are only capable of memorizing. They certainly have the ability to memorize the whole course in art history, but unfortunately, they do not have their own individual thoughts or opinions about artwork.

Joan: You gave me a $C$.

Katherine: I'm kind.

Joan: The assignment was to write about Bruegel. I did that.

Katherine: No, what you did was copy Strauss.

Joan: I was referencing an expert.

Katherine: If I wanted to know what he thought, I'd buy his book. (00:29:3900:29:53)
Finding that these girls have been trained to follow this tradition, in order to foster inspiration, Katherine asks her student Joan to think and reflect over about her assignment, instead of copying others' ideas.

However, at Wellesley, the ambition to reach personal fulfillment is taboo. Therefore, bringing liberal concepts and the feminist consciousness to students through modern art is prohibited by the president at Wellesley, who forces Katharine to follow the conventional framework of teaching if she wants to remain at the school.

President: I've been getting some calls about your teaching methods, Katherine. They're a little unorthodox, for Wellesley. We are traditionalists, Katherine.

Katherine: Yes, I noticed.

President: So if you'd like to stay here...

Katherine: Is that a question?

Presiden: More a discussion. You'll have your formal review in May. Until then... a little less modern art. (00:43:4000:44:06)

Wellesley College is truly a "college of marriage," whose responsibility is to instill the ideology of what a perfect housewife is and to implant within these female students the conventions and social norms to reach the goal of institutionalization, disciplining these girls to be marriable in the conventional marriage system. In other words, Wellesley helps these girls project the public image of a perfect wife in order to increase their value in the marriage market.

Since girls at Wellesley bear the obligation of becoming an ideal housewife in order to render themselves marriable in the marriage market, they are kept from developing their potential and from knowing the world, for these matters have nothing to do with their family's happiness. Hence, in order to get married, girls have been disciplined to waive their subjectivity and independence in exchange for financial support from their husbands. They have been trained to obey the unwritten rules and gender ideology rooted in a traditional college, thinking that they were born to be a wife. In order to accomplish their 
life goal to be an ideal wife, at Wellesley, they have been expected to cultivate themselves as refined and courteous women. Moreover, they have been raised to support and look after their husbands and children, letting their family expand like a continuous flow of water. Even if all the tasks are time-consuming, at Wellesley, girls have been trained to voluntarily shoulder the tasks, thinking that achieving matrimony means the sacrifice of their dreams and careers. The concept of sacrificing for the family is quite normal in 1950s America because, for these girls, the gender stereotypes had been firmly rooted in their youth.

Based on Becker's (1960) side bet theory, a harmonious marital relationship can be a consequence of the decision a woman makes when choosing a man to be her husband based on that man's appearance, personality, financial situation, and social status. For the family's sake, women tend to choose a man whose qualifications correspond with their own or even bring some practical benefits to them. Nonetheless, they would not take mutual affection into consideration. A marriage thus described is also called a functional marriage (Fiore \& Swensen, 1977). People need each other for the purpose of building a family, and they get married for their own benefit. However, this kind of thought will drown them in the trap of a functional marriage, a marriage focusing on function and not mutual affection. The commitment to a functional marriage corresponds to Becker's side bet theory and Homan's social exchange theory because, while choosing a husband, women would go through the cost-benefit analysis, attempting to reach the maximum benefits and to minimize any cost in their marriage.

In order to meet the social expectation and the benefits of the transactional marriage, many women fall into the trap of functional matrimony. They cannot follow their hearts and ignore the need of affection. According to the side bet theory, people generally choose a partner based on the assumption of a continued and stable matrimony and then increase their commitment to gain more benefits. Hence, based on the previous experiences of their ancestors, marriageseeking women may choose a man who is more suitable for them or choose a companion who has more prosperous conditions. It is said that women make a "side bet'" based on a main bet or activity succeeding, and the side bet therefore increases their commitment to the main bet. Conversely, if they fail at the main bet, they would also lose the side bet (Becker, 1960; Aranya \& Jacobson 1975). Hence, running a marriage becomes a form of running a business or organization, in which the main focus is on the benefit, disregarding mutual affection.

In the workplace, organizational commitment refers to the bond between employees and their organizations. Indeed, many employees, recognizing and identifying with the clear vision and goal of their organizations, form a strong and positive connection with them (Allen \& Meyer, 1990). There are three components to organizational commitment: affective commitment, continuance commitment, and normative commitment (Allen \& Meyer, 1990). However, those who care about maintaining a functional marriage would only take continuance commitment and normative commitment into consideration. Since matrimony is like running a firm or business, those getting involved in this business of marriage only need to pay through their commitment to their marriages, businesses, and organizations. Hence, regarding organizational commitment, both men and women, upon entering the marriage bind, have to make a continuous commitment to their marriage because they are aware that, once the marriage ends, their meaningful profit also ends. Therefore, in consideration of the so-called "main bet" and "side bet," they choose to stay in that marriage (Becker, 1960).

The consideration of the main bet and side bet is quite a common phenomenon in the marital relationship. Once women get divorced from their husbands, they lose the main bet, as well as the side bet. In a traditional society, even if a woman does not get married based on affection for her husband, she would still make a continual commitment to her marriage because she well knows that, once the state of matrimony starts to fade, she will lose her marriage (main bet) and then her happiness (side bet), such as the well-being and satisfaction that was derived from the 
marriage. Moreover, once a marriage is damaged, a woman's investment in it is in jeopardy. At this time, since the matrimony has suffered some form of damage, some women might decide to rid themselves of a failed marital relationship. However, other women might choose to stay with their husband because they are rooted in the belief in devotion and commitment to matrimony. Hence, regarding this normative commitment to an organization (Wiener, 1982), women may feel the need to stay in their marriage to continue working to better it, perhaps fearing that departing from the marriage system would bring disastrous consequences or perhaps simply a sense of guilt at the thought of leaving their husbands.

Therefore, those who are considering their main bet and side bet may be trapped in their marriage. Also, some may be rooted in the gender stereotype. Therefore, even if their marriage is a total failure, they would never think of divorce, for fear of the gossip. In order to avoid negative perceptions, these women would rather choose to stay in an unhealthy marital relationship instead of ending it. Moreover, they are well aware that, once they divorced their husbands, they would fall out of their comfort zone, losing their economic/financial resources and their children. Hence, in consideration of the "main bet" and "side bet," as well as their rooted gender stereotype, those women would choose to stay in a failed marriage, which becomes a bondage of matrimony in conservative society. In Mona Lisa Smile, Spencer steps out on Betty after their wedding. He thus becomes a perpetrator in the marital relationship. Betty wants to escape from a rotten marriage, but she encounters many handicaps. Her mother even asks her to tolerate Spencer's affair:

Betty's mother: You're going to turn around, go home, fix your face and wait for your husband. This is the bargain you made, Elizabeth. We all did.

Betty: So you're not going to let me stay in my own house?

Betty's mother: Spencer's house is your house now. Believe me, it's for your own good. (01:21:01-00:21:17)
To avoid being sized up with curious eyes, all Betty can do is to accept her mother's words and restrain her anger toward her husband. Hence, while knowing that her husband is having an affair and while suffering great pain, Betty takes her mother's suggestion: "There will be no divorce" (01:31:43-00:31:44). She manages to be a competent wife in order to remain in her comfort zone and maintain financial support from her husband, Spencer.

Women's insistence on staying committed to a horrible marriage in traditional society is akin to organizational commitment, a psychological attachment that a worker forms to the workplace. (Allen \& Meyer, 1990; O'Reilly \& Chatman, 1986). As Becker (1973; 1991) says that running a marriage is somewhat like running a business or organization, for those women making their family's happiness their own career, they would be wholly committing themselves to the marriage, always giving priority to their husbands and children. These women focus solely on how to be a qualified wife and mother, not how to be themselves.

A harmonious marital relationship will allow women to devote themselves to their marriage. In a conventional society, a woman has no choice but to accede to her parents' arrangement to marry a person of their choice, whose conditions are similar to hers. This is shown in the film, with Betty and Spencer. In addition, the social expectation becomes a prison; it restricts married women. Once they are married, women form a strong and positive connection to their marriage. Consequently, even if they get the short end of the marriage stick, as in a normative commitment, they will voluntarily stay in a rotten marriage because of some positive aspects that the marriage has brought to them, as well as their obligation to their family. However, this choice causes another problem: such a marriage lacks affection and contains only the fulfillment of matrimonial obligations. In addition, due to the energy and effort women have devoted to their marriage, they depend on their husbands much more deeply day by day-they are invested in the relationship. Consequently, being bound in the traditional gender stereotypes in a marital relationship, women 
are always situated in a disadvantaged position: they lack economic independence, basic human rights, personal power, and so forth. Moreover, they are limited by the conservative concept of gender ideology.

Nevertheless, fortunately, due to the outbreak of a critical World War II, the gender character quietly changed. Women's social status became more advanced, and their gender status indirectly improved.

\section{World War II and Feminist Consciousness}

World War II awoke the feminist consciousness and broke the stereotypes of gender roles. In a patriarchal society, men always serve as functional characters, and women must be more emotional and caring. That is, in a stereotypical patriarchal family, husbands would work outside the home in order to bring food to their family, while women would raise children and maintain the household. Before World War II, women who had to work outside the home were members of the lower class, and people would take a negative attitude toward them. However, the outbreak of World War II (1939-1945) incurred the need of the military and the demand of workers to maintain a stable economy. Hence, a great number of women were encouraged to step into the workforce, no longer limited to staying at home and taking care of the household (Lamb, 2011). Women's capability to step into the workforce brought about a great change in gender ideology and, hence, deconstructed the conventional gender stereotypes. Moreover, with the initiation of feminist movement in the USA of 1950, women's gender consciousness has been changed from the conservative to the feminist and hence those women in Mona Lisa Smile began to realize their potential and subjectivity.

In addition, with the outbreak of World War II, the shattering of gender stereotypes let American women have a chance for more social interactions, for instance, working for the Women Airforce Service as pilots or in hospitals as nurses (Granger, 1991; Lamb, 2011), thereby bringing glory to their country and family. While serving as Women Airforce
Service pilots (Martin, 2020), women flew to protect their country and to seek their freedom. While the traditional social norms were being challenged, feminist consciousness was awakening (Tong, 1995), and it continued to do so even though, after the war, women were forced to return home. They then faced the dilemma of either having a career but staying unmarried, or being a wife but giving up the idea of having a career (Lamb, 2011).

Aside from the transition of gender awareness and social interactions, selfrecognition is also a key point for avoiding the box of traditional marriage, the bondage of matrimony. Owing to the transition of gender awareness, women after World War II had more freedom in their marital relationship than those before. This kind of change caused some significant effects on women's ways of thinking and deeply altered their thoughts toward marriage and the marital relationship. To this end, Katherine noted, "Pearl Harbor happened and everything changed" (00:58:2800:58:30). Since World War II, women have increased their gender consciousness and have given different definitions to the word "marriage."

Susan: Was he changed?

Katherine: They both were. I'm sorry.

Katherine: Your parents?

Giselle: Yeah. After the war...they didn't know each other anymore, didn't like each other. He left. He got a whole new family.

Susan: Divorce.

Giselle: What? Yeah. First on my block. That's a city block.

Katherine: People change. Things happen. It's the same with me and Leo. He went off and married someone else. And I got to go to graduate school.

Connie: UCLA, right? Which is in Hollywood?

Katherine: It's close.

Giselle: Anyway, aren't you gonna tell Everybody about, you know.. your big news?

Joan: What are you talking about?

Giselle: She got engaged over Christmas!

Connie: Congratulations!

Joan: I'm sorry to blab. It's just so romantic. How fantastic! 
Katherine: We split up.
Joan: What?

Katherine: We split up. Well, that was fast. Well, not every relationship is meant for marriage. (00:58:37-00:59:52)

Although, after the end of the war, women were forced to return home to take on the traditional role of an ideal wife, as well as an ideal mother, and to surrender their jobs to the returning men, the occurrence of the second world war had allowed women to awaken their feminist consciousness and think about the traditional social norms and gender stereotypes. As a result, in 1950, various feminist movements began to spring up (Lamb, 2011). Many propagandists advocated for social, economic, and even political equality for women. Thus, with gender awareness, women began to possess power on their own instead of waiting for support from men. Female subjectivity, referring to women as independent subjects and not objects (Beauvoir, 1997; Kristeva, 1981), is highlighted in Mona Lisa Smile when Susan asks Katherine, "Won't you regret never marrying?" and Katherine replies, "I'm not gonna plan my life around it" (01:00:2401:00:35). With the awareness of gender equality and subjectivity, women no longer needed marriage for security. As Katherine implies, the change of the gender role and awakening of feminist consciousness have elevated women's attitude toward matrimony. Women could lead satisfying lives and follow their minds instead of following traditional rules, as Katherine explains to Bill:

Bill: You know, if you were mine, I'd never let you go.

Katherine: I wouldn't have asked your permission. (00:27:00-00:27:04)

With gender awareness and autonomy, women, like Katherine, had a chance to enter the workplace and have access to higher educational institutions. They could be independent and listen to their inner voices without compromise. Indeed, Lamb (2011) noted that, as women gradually shed the gender stereotypes, the rise of feminist consciousness jointly affected the marriage institution and the ideology of marriage and companionship.

\section{Transformation-Feminist Consciousness and the Bondage of Matrimony}

In Mona Lisa Smile, only Katherine believes that girls should have their own rights regarding matrimony. Other faculty, including President Carr, believe that girls do not deserve to have these rights. At Wellesley, with rooted gender stereotyping, the girls dare not dream about their careers; instead, they must prepare to sacrifice themselves in matrimony - at least, until the appearance of Katherine, a teacher who inspires these girls to find and discover their self-cognition through literature and art. For example, Katherine encourages Joan, her student, to imagine and fulfill her dream.

Katherine: Yes, you do, but a very busy one. And it says here that you're pre-law. What law school are you gonna go to?

Joan: I hadn't thought about that. After I graduate, I'm getting married.

Katherine: And then?

Joan: And then I'll be married.

Katherine: You can do both. Just for fun, if you could go to any law school, which would it be?

Joan: Yale. Yale.

Joan: They keep five slots open for women, one unofficially for a Wellesley girl.

Katherine: But you haven't really thought about it. (00:30:33-00:31:04)

With the awakening of feminist consciousness, women realize that they do not need to choose between having a family life and having a career. They could have both or choose either at their free will. As shown in the passage, Katherine declares that women do not need to choose between being a housewife and having a career; they can have both at the same time. Hence, Katherine encourages Joan to study for her future career, while running her family life. Further, by means of the appreciation and reproduction of art, Katherine attempts to prompt students to break free of their conservative thoughts, saying that "No one 
needs to own a van Gogh original" (00:53:4500:53:48).

Katherine: They can paint their own. Van Gogh in a box, ladies. The newest form of mass-distributed art: Paint by numbers.

Connie: Now everyone can be van Gogh. It's so easy. Just follow the simple instructions and in minutes, you're on your way to being an artist.

Giselle: Van Gogh by numbers?

Katherine: Ironic, isn't it? Look at what we have done to the man. who refused to conform his ideals to popular taste. Who refused to compromise his integrity. We have put him in a tiny box and asked you to copy him. So the choice is yours, ladies. You can conform to what other people expect or you can... (00:53:57-00:54:38)

Unlike other faculty at Wellesley, Katherine encourages students to be inspired by art, thinking that every girl has the potential to become van Gogh or another artist.

In addition to the freedom to choose their career, women also have more freedom to choose their husbands based on love. Women who successfully increase their selfrecognition must recognize and heed their inner voice. On the aspect of matrimony, they will choose the person they truly love; they will gain freedom and affection in their marriage. They will marry neither for social status nor traditional stereotypes: They marry for affection. This type of choice indicates the fulfillment of affective commitment. "Affective commitment" refers to the belief and the acceptance of the value of an organization. Subsequently, it indicates the value of a person who participates in a specific organization (Mowday, Porter, \& Steers, 1982). With this concept, marriage in a liberal society is much more comfortable than that of a conservative generation. With the former, women enter a marital relationship with meaningful beliefs and acceptance, not merely as a means to maintain their current lifestyle. In an affectionate marriage, they will be much more willing to maintain the relationship, as Joan, based on affective commitment, highlights by refusing to attend law school because of her family.

Joan: It was my choice. Not to go. He would have supported it.

Katherine: Butyou don't have to choose.

Joan: No, I have to. I want a home, a family. It's not something I'll sacrifice.

Katherine: No one's asking you to sacrifice that, Joan. I just want you to understand that you can do both. And marriage is not an obstacle for women to get education and maybe that education makes you become a lawyer.

Joan: Think I'll wake up one day and regret not being a lawyer?

Katherine: Yes, I'm afraid that you will.

Joan: Not as much as I' regret not having a family. Not being there to raise them. I know exactly what I'm doing, and it doesn't make me any less smart.

Joan: This must seem terrible to you.

Katherine: I didn't say that. L...

Joan: Sure you did. You always do. You stand in class and tell us to look beyond the image, but you don't. To you, a housewife is someone who sold her soul for a center hall colonial. She has no depth, no intellect, no interests. You're the one who said, I could do anything I wanted.

Joan: This is what I want. (01:22:2201:23:15)

To Joan, her family is not her means for profit or a side bet any longer. She stays in her marriage because of love and her own volition (Becker, 1960). Joan's decision is made based on her strong connection to her partner. In contrast to traditional women who have no choice, who must make a decision between being a housewife or having a career, Joan can freely choose to be a housewife, giving up her intention to enter law school. Instead of stepping into a marriage to fit into the image of an ideal woman and a perfect wife to meet the expectations of social norms, Joan, with feminist autonomy, listens to her own inner voices and takes the female identity she would like to have. 


\section{Breaking Gender Stereotyping through Self-Representation}

In a traditional society, with rooted gender ideology, women are expected to mate with a "suitable" person and to behave accordingly in order to meet the expectations of others. Hence, it is held that men should display the characteristics of dominance, social boldness, and emotional stability. In contrast, women should be self-reliant, sensitive, and apprehensive. Men are expected to handle all external means of supporting their family; on the other hand, women should be responsible for all the internal housework (Lamb, 2011). Hence, in order not to be judged, women must act in a manner fitting the normative regulation. This phenomenon falls into what Goffman (1959) calls the "fake role." Women must act within a fixed gender frame in public in accordance with social expectations (Goffman, 1977; The'baud, Kornrich, \& Ruppanner, 2019). For instance, women should be submissive and obedient, while men should be assertive and ambitious. Betty's mother exemplifies this notion by suggesting that Betty recite a love poem to her fiance at their wedding ceremony, but let others know that everything was her husband's idea.

\section{Betty: Oh, I almost forgot. I spoke to him about reading the poem. He'd rather not. I said all right.}

Betty's mother: Excuse us for a second, Joan. A good wife lets her husband think that everything's his idea. (00:22:41-00:22:59)

Betty's mother advises Betty not to be an assertive woman, but instead, to be a submissive wife while her image and her marital relationship are on display. In other words, she suggests that Betty develop and maintain an image in terms of approved social norms. In marriage during this time, women relied on men for caring and financial support, as men always adopted the dominant role. Even if their husbands had an affair and became a perpetrator, women were told to tolerate the indiscretion. They could not even leave a failed marriage because divorce was considered scandalous by conservative society. That is why, when Betty finds out that Spencer betrayed her, her mother is extremely opposed to her taking any action or even telling anyone. According to Betty's mother, "Don't wash your dirty laundry in public" (01:32:20-01:32:23), In fact, Betty's mother intends to present a certain (fake) face to the public, as, according to Goffman (1972), a fake face follows social norms. However, the fake face is definitely proof of the gender stereotype that causes women to suffer in their marriage. In this kind of transactional marriage, matrimony is bound by feudal rules and traditional social norms. It is a consequence brought about by people's behavior in meeting the standard of society. In fact, matrimony itself is a brutal truth covered by a glorious appearance, the actual fake face, according to Goffman (1959), in a conservative society. On the other hand, the truth, the real face, will be uncovered through the passage of time. Therefore, in a marriage without affection, although a woman may wear a fake face, someday, her true face will reveal itself, and the so-called "happiness" will ultimately break down.

With feminist consciousness, women began to grasp their autonomy, eschewing the need to stay at home all day long to provide household services to their husband and children (Lamb, 2011). Hence, even stuck in a loveless marriage, Betty is torn between being an obedient housewife in order to meet the expectations of others and being an independent woman, listening to her inner voice. Though she has tried hard to listen to her mother's suggestions and to adjust to her housewife role, with raising awareness of feminist consciousness, Betty cannot ignore the fact that her husband has a mistress outside. It is no longer possible for Betty to pretend that nothing has happened in her marriage. Instead, she turns to listen to her own inner voice, declaring that she has no intention of inheriting conservative gender roles. She decides to end her failure of a marriage in divorce, saying, "I filed for a divorce this morning" (01:38:08-01:38:11). With increasing gender awareness, finally, Betty requests for a divorce to claim for gender equality. Moreover, she begins to pursue her own professional life: "Maybe law school. Yale, even" (01:38:54-01:38:56). 
Katherine, meanwhile, is indoctrinated by feminist self-identification and gender awareness. She symbolizes the shape of feminist identification in future society, as she dares to challenge the college president, Miss Carr, a president who was brainwashed by patriarchal thought. Hence, the president loses, or never had, her female consciousness. In contrast, Katherine, with feminist consciousness, holds beliefs that differ from others' and devotes herself to teaching girls to reflect over the intrinsic value of art and the intrinsic values of being a woman. While other women were stuck in the traditional ideology of art and gender stereotypes, Katherine's actions to help these girls to consider their inner value and build up their intrinsic values and subjectivity are thought of as impropriety.

Katherine: There are a lot of labels here. I've noticed. Right family, right school, right art, right way of thinking.

Bill: Well, saves the effort on thinking for yourself. (00:27:14-00:27: 24)

At that time, Katherine's quest for a liberal spirit and autonomy is recognized as rudeness, subversion, and a disregard of traditions in the conservative college. However, using art as a means to help these students reflect over their intrinsic values and subjectivity further arouses students' feminist consciousness and subjectivity. Betty and Spencer's marriage demonstrates that, when a marriage has been used to fulfill the expectation of a society, women, as well as men, become victims in the marital relationship. Fortunately, with the assistance of Katherine and the awareness of feminist consciousness, Betty divorces her unfaithful husband. With increasing gender awareness, Betty decides not to compromise any longer. Instead, she dares to ignore her mother's conservative framework and breaks through the "box" of traditional marriage (the bondage of matrimony), realizing that a woman should not be sacrificed for a man, but should be her own individual, reaching her own self-fulfillment.

\section{Conclusion}

Mona Lisa Smile is a micropicture of the situation affecting women in America in the 1950s. Girls, like those shown at Wellesley
College, were disciplined to follow the conventional gender ideology: to prepare themselves to be a perfect housewife, while sacrificing their thoughts and subjectivity.

With rooted gender stereotypes and gender ideology, traditional gender ideology and a conservative social frame led women to gradually erode their time and freedom. Thanks to the feminism movements, women began to raise their gender consciousness. The scenarios in the film Mona Lisa Smile let readers have a chance to see the transformation of a marital relationship from the old days to modern ones. Readers may be inspired by Katherine, Joan, and Betty in Mona Lisa Smile to learn how to fight for women's rights, discard the prison constructed of social and gender expectations, and abandon the box of matrimony.

With increased gender awareness, women can deconstruct gender ideology, and hence, find their own will, thereby providing different definitions for the word "marriage."

\section{References}

Allen, N. J., \& Meyer, J. P., (1990). The measurement and antecedents of affective, continuance and normative Commitment to the organization. Journal of Occupational Psychology, 63(1), 1-18. http://dx.doi.org/10.1111/j.20448325.1990.tb00506.x

Aranya, N., \& Jacobson, D. (1975). An empirical study of theories of organizational and occupational commitment. Journal of Social Psychology,97(1), 15-22. https://doi.org/10.1080/00224545.197 5.9923308

Babbie, E. (1995). The practice of social research. Belmont: Wadsworth Publishing Company.

Beauvoir, S. (1997). The second sex. Trans. H. M. Parshley. London: Vintage.

Becker, H. S. (1960). Notes on the concept of commitment American Journal of 
Sociology,

66 ,

32-42. https://doi.org/10.1086/222820

Becker, G. S. (1973). A theory of marriage: Part I. Journal of Political Economy, 81, 813846. https://doi.org/10.1086/260084

Becker, G. S. (1991). A treatise on the family. London: Harvard University Press.

Buss, D. M. (1984). Marital assortment for personality dispositions: Assessment with three different data sources. Behavior Genetics, 14 (2), 111123. https://doi.org/10.1007/BF010764 08

Castro, G. (1990). American feminism: A contemporary history. Paris: Presses de la Fondation Nationale des Sciences Politiques.

Friedan, B. (1997). The feminine mystique. New York, NY: W.W. Norton \& Company.

Granger, B. H. (1991). On final approach: The women airforce service pilots of World War II. Scottsdale, Arizona: Falconer Publishing Company.

Homans, G. C. (1961). Social behavior: Its elementary forms. New York: Harcourt, Brace \& World.

Fiore, A., \& Swensen, C. H. (1977). Analysis of love relationships in functional and dysfunctional marriages. Psychological Reports, 40(3), 707-714. https://doi.org/10.2466/pr0.1977.40.3.7 07

Goffman, E. (1959). The presentation of self in everyday life. Garden City, NY: Doubleday.

Goffman, E. (1977). The arrangement between the sexes. Theory and Society, 4(3):301331.

https://doi.org/10.1007/BF00206983

Konner, L., \& Rosenthal, M. (2002). Mona Lisa Smile [script]. Los Angeles: Columbia Pictures.

Kristeva, J. (1981). Woman can never be defined. Trans. Marilyn A. August. In E. Marks \& I. Courtivron (Eds.), New French feminisms (pp. 137-141). New York: Schoken Books.

Lamb, V. M. (2011). The 1950's and the 1960's and the American Woman: the transition from the "housewife" to the feminist
(Thesis). Toulon, France: University of Toulon.

Lawler, E. J. (2001). An affect theory of social exchange. American Journal of Sociology, 107(2), 321-352. https://doi.org/10.1086/324071.

Millett, K. (1985). Sexual politics. London: Virago Press.

Mowday, R.T., Porter, L. W., \& Steers, R.M. (1982). Employee-organization linkages: The psychology of commitment, absenteeism, and turnover. New York: Academic Press.

Newell, M. (1993). Mona Lisa Smile. Los Angeles: Revolution Studios and Columbia Picture.

O'Reilly, C. A, \& Chatman, J. (1986). Organizational commitment and psychology attachment: The effects of compliance, identification, and internalization on prosocial behavior. Journal of Applied Psychology, 71(3), 492499. https://doi.org/10.1037/00219010.71.3.492

Wiener, Y. (1982). Commitment in organizations: A normative review. Academy of Management Review, $7(3)$, 418-428. https://doi.org/10.5465/amr.1982.4285 349

The'baud, S., Kornrich, S., \& Ruppanner, L. (2019). Good housekeeping, great expectations: Gender and housework norms. Sociological Methods \& Research, 1-29. https://doi.org/10.1177/004912411985 2395

Tong, R. (1995). Feminist thought. London: Routledge. 